\title{
EFFECT OF DIETARY SUPPLEMENTATION OF PROBIOTIC, PHYTOBIOTICS OR THEIR COMBINATION ON PERFORMANCE, BLOOD INDICES AND JEJUNAL MORPHOLOGY OF LAYING HENS DURING POST PEAK PRODUCTION
}

\author{
Rahmad HIDAYAT, Vitus Dwi YUNIANTO, Bambang SUKAMTO and Sugiharto SUGIHARTO \\ Department of Animal Science, Faculty of Animal and Agricultural Sciences, Universitas Diponegoro, Semarang, Central Java, Indonesia \\ Email: sgh_undip@yahoo.co.id ; (D) ORCiD: 0000-0003-2445-0543 \\ supporting Information
}

\begin{abstract}
The purpose of this study was to evaluate the effect of dietary supplementation of probiotic (Lactobacillus acidophilus), phytobiotics (bay leaves, onion peel and garlic peel) or their combination on blood parameters, morphology of digestive tract and performance of laying hens. The experiment used 144 laying hens aged 72 weeks old, and divided into 6 treatments including Ctl (basal feed as control); Pr (basal feed + $1.2 \mathrm{~mL} /$ day of probiotic $L$. acidophilus); Ph2 (basal diet $+2 \%$ phytobiotic of diet); PrPh2 (basal diet +1.2 $\mathrm{mL} /$ day probiotic $+2 \%$ phytobiotic); PrPh4 (basal diet $+1.2 \mathrm{~mL}$ /day probiotic $+4 \%$ phytobiotic) and PrPh6 (basal diet $+1.2 \mathrm{~mL} /$ day probiotic $+6 \%$ phytobiotic). Feed intake and egg mass were weekly recorded. One chick from each replicate was blood sampled and then slaughtered for data collection. Results showed that treatments had no effect on hemoglobin, erythrocyte and leukocyte of hens. The control hens had higher levels of cholesterol and LDL than that of PrPh2, PrPh4 and PrPh6 hens. HDL level tended to be higher in PrPh2 and PrPh4 as compared to control hens. Compared to control, the villi height of jejunum was higher in the treated hens, with PrPh4 had the highest villi height. Ileal protein digestibility tended to be higher in the treated than that in control hens. Also, there was a clear tendency that feed conversion ratio was lower in the treated hens than that of control. In conclusion, the combined use of probiotics and phytobiotics improved physiological condition, ileal histomorphology, ileal protein digestibility and feed conversion of laying hens during post peak production.
\end{abstract}

Keywords: Garlic, Herb, Laying Hen, Phytobiotic, Probiotic.

\section{INTRODUCTION}

Egg production declines after laying hens reaching the peak of production. Antibiotic growth promoters (AGP) was often administrated to feed to slowdown the declining rate in egg production after the peak production (Salim et al., 2018). In the digestive system, AGP plays a function in eliminating pathogenic bacterial populations in order to maximize nutrient absorption by hens (Purbarani et al., 2019). In recent years the use of AGP has been banned in many countries, including Indonesia. This is due to several negative effects of AGP, e.g., there is residue that found in livestock products, so that it can endanger human health. These health risks include bacterial resistance, allergies to the products consumed, the high risk of illness from poisoning, etc. (Deko et al., 2018).

Various alternatives to AGP substitute for poultry have been studied, one of which is probiotics (Sugiharto et al., 2017). One of the most widely used probiotic bacteria in the poultry industry is Lactobacillus achidophilus (Saputra et al., 2020). Indeed, the use of $L$. acidophilus was reported to improve physiological conditions, health status (Siadati et al., 2017), growth of intestinal villi (Hedayati and Manafi, 2018), nutrient digestibility and performance of poultry (De Cesare et al., 2017). Another alternative ingredient that can be used as a substitute for AGP are herbal ingredient or phytobiotics (Haniarti et al., 2019). Phytobiotic that can be used as feed additive in poultry include bay leaves (Santoso et al., 2017), garlic peel (Benítez et al., 2011) and onion peel (Rahmawati et al., 2019). Previous studies have reported that bay leaf flour added to feed has an effect on the microflora of the digestive tract of broiler chickens (Sjofjan et al., 2019). Meanwhile, the use of garlic and onion peels and their combination in feed could increase the digestibility of feed protein and performance of duck (Saputra et al., 2016) and reduce triglyceride levels in the blood of broiler chicken (Kim et al., 2009). Besides having a high flavonoid content, these herbal ingredients have also been reported to contain oligosaccharides which can act as prebiotics, which are useful for the growth of probiotic bacteria (Babbar et al., 2016).

To increase its effectiveness as an alternative to AGP, probiotics are often combined with other active ingredients such as phytobiotics. Chang et al. (2019) reported that multi strains of probiotics supplemented with herb (Gardeniae fructus) can suppress the growth of pathogenic bacteria and increase the growth of the intestinal villi of broiler chickens. The combination of $L$. acidophilus with Dayak onion extract added to feed could also improve nutrient digestibility, health conditions and performance of broilers (Yuanita et al., 2019). Likewise, the combined use of Lactobacillus spp. and ginger and turmeric extracts improved production performance and health parameters of broilers (Risdianto et al., 2019). 
To best of our knowledge, the use of a combination of probiotic (L. acidophilus) and phytobiotic from bay leaves, onion and garlic peels on laying hens during the post peak production has never been reported. Therefore, the study aimed to determine the influence of dietary administration of probiotic L. acidophilus, phytobiotics (bay leaves, onion and garlic peels powders) or their combination on blood profile, jejunal morphology and the performance of laying hens.

\section{MATERIALS AND METHODS}

The study used 144 of laying hens (Isa Brown strain) post peak production, aged 72 weeks (weight $1.98 \pm 0.1 \mathrm{~kg}$ ). The hens were raised for 5 weeks (35 days). The feed ingredients used in this study included yellow corn, rice bran, soybean meal, meat bone meal, fish meal, salt, grit, methionine, premix, onion peel (OP), garlic peel (GP) and bay leaf (BL). Feeds were offered to hens ad libitum with free access to water throughout the experiment. The phytobiotic combination used was $50 \%$ of $\mathrm{BL}, 25 \% \mathrm{OP}$ and $25 \%$ GP. The probiotic bacteria used was $L$. acidophilus $\left(10^{8} \mathrm{cfu} / \mathrm{mL}\right)$. Details of the composition of feed ingredients and treatment are listed in Tables 1 and 2 while the nutritional content of phytobiotics is in Table 3.

This study was arranged according to a completely randomized design with 6 treatments and 4 replications, with 6 hens in each replicate. The treatments included Ctl (basal feed as control); $\operatorname{Pr}$ (basal feed $+1.2 \mathrm{~mL} / \mathrm{day}$ of probiotic $L$. acidophilus); Ph2 (basal diet $+2 \%$ phytobiotic of diet); PrPh2 (basal diet $+1.2 \mathrm{~mL} /$ day probiotic $+2 \%$ phytobiotic); PrPh4 (basal diet $+1.2 \mathrm{~mL} /$ day probiotic $+4 \%$ phytobiotic) and PrPh6 (basal diet $+1.2 \mathrm{~mL} /$ day probiotic $+6 \%$ phytobiotic)

Weekly feed intake and egg mass were recorded. Feed conversion was calculated by dividing the average feed consumption by the average egg mass for a week. Two $\mathrm{mL}$ of blood sample was taken on day 34 of the experiment through the brachial vein and put into a tube containing ethylene diamine tetraacetic acid (EDTA) and stored in a cooling box for further analysis. The determinations of cholesterol, low-density lipoprotein (LDL) and high-density lipoprotein (HDL) levels were conducted based on the enzymatic-colorimetric method. The enumeration of erythrocytes and leukocytes was carried out using a hemocytometer, while hemoglobin levels were determined using the Sahli-Hellige method (Sufiriyanto et al., 2018). At 35 days of study, one hen was taken from each replicate then slaughtered. Shortly after slaughter, the jejunal segment was obtained for the measurement of $\mathrm{pH}$ values, length, weight (empty weight) and villi height. Digesta samples from ileum were also taken for the calculation of crude protein content according to the method as described by Lemme et al. (2004).

\begin{tabular}{lc}
\hline \multicolumn{2}{l}{ Table 1 - Ingredients of basal diet } \\
\hline Ingredients & Composition (\%) \\
\hline Maize & 54.9 \\
Rice bran & 8.84 \\
Soybean meal & 19.2 \\
Meat bone meal & 6.29 \\
Fish meal & 1.00 \\
Salt & 0.28 \\
Limestone & 7.88 \\
Methionine & 0.05 \\
Premix & 1.50 \\
TOTAL & 100
\end{tabular}

\begin{tabular}{lc}
\hline Table 2 - Nutritional contents of basal diet \\
\hline Nutrient composition & Contents8 \\
\hline $\begin{array}{l}\text { Metabolizable energy } \\
\text { (kcal/kg) }\end{array}$ & 2,654 \\
Crude protein (\%) & 17.3 \\
Crude fat (\%) & 3.51 \\
Calcium (\%) & 5.55 \\
Phosphorus (\%) & 0.66
\end{tabular}

\begin{tabular}{lc}
\hline $\begin{array}{l}\text { Table } 3- \\
\text { phytobiotics (combined }\end{array}$ & $\begin{array}{c}\text { Nutritional } \\
\text { content }\end{array}$ \\
\hline Nutrient & $\begin{array}{c}\text { Compositions } \\
(\%)\end{array}$ \\
\hline Dry matter & 87.55 \\
Crude protein & 8.58 \\
Crude fat & 1.63 \\
Crude fiber & 34.08 \\
Calcium & 1.20 \\
Phosphorus & 0.28
\end{tabular}

\section{Statistical Analysis}

The data were analyzed using analysis of variance (ANOVA) with a significance level of $5 \%$. When the treatment showed a significant effect $(p<0.05)$, the Duncan multiple range test was then performed. The obtained results were expressed as the mean \pm standard deviation.

\section{Ethical approval}

The in vivo study was supervised by the Animal Ethics Committee of the Faculty of Animal and Agricultural Sciences, Universitas Diponegoro and conducted in accordance with the basic animal husbandry and health protocols referred to in Legislation of the Republic of Indonesia No. 18, 2009.

\section{RESULTS}

Data on blood profile of laying hens are presented in Table 4. It was shown that treatments had no effect ( $p>0.05)$ on hemoglobin levels, erythrocyte counts and leukocyte numbers of laying hens during post peak production. Table 5 demonstrates the data on concentrations of cholesterol, LDL and HDL in the plasma of laying hens. The control hens had higher levels of cholesterol $(p=0.05)$ and LDL $(p<0.05)$ than that of PrPh2, PrPh4 and PrPh6 hens. HDL level tended to be higher $(p=0.08)$ in PrPh2 and PrPh4 as compared to control hens. Data on the conditions of jejunal segments of laying hens are presented in Table 6. Compared to control, the villi height of jejunum was higher $(p<0.05)$ in the treated hens, 
with PrPh4 had the highest villi height. The treatments had no substantial effect on the relative weight and length as well as $\mathrm{pH}$ values of jejunum. Table 7 shows the data on ileal protein digestibility and performance of laying hens. Ileal protein digestibility tended $(p=0.06)$ to be higher in the treated than that in control hens. Also, there was a clear tendency $(p=0.05)$ that feed conversion ratio was lower in the treated hens than that of control. Yet, there was no significant effect of the treatments on the feed intake per week and egg mass per week.

\section{Table 4 - Blood profile of laying hens}

\begin{tabular}{|c|c|c|c|c|c|c|c|}
\hline Variables & CtI & Pr & Ph2 & PrPh2 & PrPh4 & PrPh6 & p-value \\
\hline Hemoglobin (g/dL) & $7.20 \pm 0.12$ & $7.57 \pm 0.28$ & $7.20 \pm 0.01$ & $7.60 \pm 0.07$ & $7.50 \pm 0.12$ & $7.40 \pm 0.14$ & 0.27 \\
\hline Erythrocytes (x106) & $2.23 \pm 0.12$ & $2.57 \pm 0.77$ & $2.75 \pm 0.19$ & $2.61 \pm 0.24$ & $2.56 \pm 0.06$ & $2.64 \pm 0.16$ & 0.32 \\
\hline Leukocytes $\left(10^{3} / \mathrm{mm}^{3}\right)$ & $9.05 \pm 1.11$ & $9.13 \pm 1.26$ & $8.98 \pm 0.98$ & $8.82 \pm 0.60$ & $9.20 \pm 0.98$ & $9.07 \pm 1.14$ & 0.99 \\
\hline
\end{tabular}

Table 5 - Plasma profile of laying hens

\begin{tabular}{|c|c|c|c|c|c|c|c|}
\hline Variables & Ctl & Pr & Ph2 & PrPh2 & PrPh4 & PrPh6 & p-value \\
\hline Cholesterol & $211 \pm 9.1$ & $178 \pm 9.1$ & $174 \pm 6.9$ & $170 \pm 5.2$ & $170 \pm 10.5$ & $172 \pm 23.3$ & 0.05 \\
\hline HDL & $36.26 \pm 1.9$ & $44.4 \pm 3.6$ & $41.4 \pm 2.8$ & $49.6 \pm 3.4$ & $45.5 \pm 2.9$ & $44.4 \pm 2.4$ & 0.08 \\
\hline LDL & $112 \pm 6.4^{a}$ & $85.7 \pm 14.4^{a b}$ & $83.9 \pm 1.9 \mathrm{ab}$ & $75.3 \pm 9.5^{b}$ & $74.1 \pm 13.1^{b}$ & $61.0 \pm 7.7^{b}$ & 0.04 \\
\hline
\end{tabular}

\section{Table 6 - Jejunal segment of laying hens}

\begin{tabular}{|c|c|c|c|c|c|c|c|}
\hline Variables & CtI & Pr & Ph2 & PrPh2 & PrPh4 & PrPh6 & p-value \\
\hline Relative weight (\% BW) & $1.00 \pm 0.07$ & $0.93 \pm 0.09$ & $0.93 \pm 0.06$ & $0.94 \pm 0.06$ & $1.00 \pm 0.09$ & $1.01 \pm 0.19$ & 0.89 \\
\hline Relative length $(\mathrm{cm} / \mathrm{kg} \mathrm{BW})$ & $31.6 \pm 0.89$ & $35.0 \pm 3.28$ & $32.3 \pm 1.23$ & $30.6 \pm 0.55$ & $32.6 \pm 0.71$ & $33.2 \pm 1.76$ & 0.79 \\
\hline pH & $6.30 \pm 0.09$ & $6.15 \pm 0.13$ & $6.08 \pm 0.05$ & $6.08 \pm 0.02$ & $6.05 \pm 0.05$ & $6.05 \pm 0.03$ & 0.17 \\
\hline Villi height $(\mu \mathrm{m})$ & $812 \pm 88.2^{c}$ & $971 \pm 14.1^{b}$ & $941 \pm 11.1^{b}$ & $972 \pm 13.2^{b}$ & $1097 \pm 20.3^{a}$ & $1055 \pm 10.6^{\mathrm{ab}}$ & $<0.01$ \\
\hline
\end{tabular}

\section{Table 7 - lleal protein digestibility and performance of laying hens}

\begin{tabular}{|c|c|c|c|c|c|c|c|}
\hline Variables & Ctl & Pr & Ph2 & PrPh2 & PrPh4 & PrPh6 & p-value \\
\hline Ileal protein digestibility & $60.5 \pm 0.72$ & $70.6 \pm 2.43$ & $72.5 \pm 8.17$ & $75.5 \pm 3.04$ & $75.6 \pm 0.01$ & $76.3 \pm 0.33$ & 0.06 \\
\hline Feed intake/week & $711 \pm 10.9$ & $680 \pm 9.49$ & $675 \pm 11.12$ & $694 \pm 34.1$ & $693 \pm 31.9$ & $679 \pm 7.68$ & 0.83 \\
\hline Egg mass/week & $319 \pm 16.1$ & $339 \pm 4.09$ & $328 \pm 7.59$ & $346 \pm 22.7$ & $353 \pm 22.8$ & $354 \pm 12.1$ & 0.59 \\
\hline Feed conversion ratio/week & $2.24 \pm 0.12$ & $2.00 \pm 0.05$ & $2.06 \pm 0.03$ & $1.99 \pm 0.04$ & $1.97 \pm 0.4$ & $1.93 \pm 0.09$ & 0.05 \\
\hline
\end{tabular}

\section{DISCUSSION}

Data on blood profiles of laying hens in this study were consistent with Abudabos et al. (2016) who reported that the use of probiotics, phytobiotics or a combination of both did not have any negative impact on the physiological conditions of laying hens. With regard to probiotic effect, Siadati et al. (2017) used probiotic Lactobacillus (L. crispatus, L. salivarius, $L$. crispatus and $L$. oris) and noticed no significant effect on haemoglobin and erythrocyte levels of Japanese quails. Also, Mateova et al. (2008) did not find any effect of $L$. fermentum on the number of leukocytes of broiler chicken. In term of phytobiotics, the addition of phytobiotics (onions, ginger, turmeric and cutcherry) did not significantly affect the levels of hemoglobin, erythrocytes and leukocytes of Tegal ducks and Muscovy ducks in the study of Ismoyowati et al. (2019). In contrast to our present results, Deraz (2018) reported that probiotics (Lactococcus lactis ssp. Lactis and Lactobacillus plantarum) increased the levels of haemoglobin, erythrocytes and leukocytes in broiler chickens. Likewise, the combination of phytobiotics increased the levels of hemoglobin, erythrocytes and leukocytes in laying hens (Tang et al., 2017). The variations in probiotic bacteria species or strains, levels of probiotics, types and levels of phytobiotics, animals used in the experiment and experimental conditions may be attributed to the divergent results above. 
Data in the present study showed that cholesterol and LDL concentrations were lower in the plasma of laying hens treated with the combination of probiotic L. acidophilus and phytobiotic based on bay leaves, onion and garlic peels. Indeed, the effect of single administration of probiotic or phytobiotic alone did not affect the levels of cholesterol and LDL in the plasma of laying hens. In this respect, the synergistic or complementary effect between probiotic bacteria and phytobiotic seemed to reduce the levels of plasma cholesterol and LDL. This inference was supported by Rahman et al. (2019) showing the synergistic work of probiotic Bacillus and commercial phytobiotic (Galibiotic $\circledast$ ) in lowering the concentration of cholesterol and LDL in the plasma of broilers. It has been known that probiotic L. acidophilus could produce bile salt hydrolase, which can deconjugate bile salts to lower cholesterol (Jahanian and Ashnagar, 2015). Likewise, flavonoids content in phytobiotics could inhibit de novo cholesterol formation. In the latter case, flavonoids can inhibit the formation of acetyl co-A, which is the main precursor for cholesterol formation (Zeka et al., 2017). In this study, HDL level tended to increase with dietary inclusion of probiotic, phytobiotics or combination of both as compared to control. This result was in agreement with Krauze et al. (2020) reporting the effective impact of probiotic Bacillus subtilis and phytobiotic (cinnamon oil) in enhancing the HDL level in the serum of broiler chicken. It was most likely that the complementary effect between probiotic and phytobiotic occurred in this study as the plasma HDL level was higher in PrPh2 when compared with that in Pr, Ph2 and Ctl hens.

The laying hens used in this study were quite old (72 weeks of age), and that the growth and development of the intestine of these hens had been stopped. For this reason, the relative length and weight of jejunum were not different across the treatment groups. In general, $\mathrm{pH}$ values can be used to indicate the condition of digestive tract, which is related to the numbers of pathogenic bacteria and good bacteria. In this study, the jejunal pH values of hens were within the normal values, as Purbarani et al. (2019) noticed that the pH values of jejunum ranges from 5.80 to 6.90 . In this study, the jejunal villi height increased with the dietary administration of probiotics, phytobiotics and their combination. This seemed due to the antibacterial activity of probiotics and phytobiotics, which may reduce the pathogenic bacteria load in the intestinal villi (Hussein et al., 2020). The latter condition may consequently improve the growth and development of the intestinal villi (Hedayati and Manafi, 2017).

In this study, the increased ileal protein digestibility seemed to be attributed to the increased jejunal villi height of hens. The higher the intestinal villi implied in the wider surface area for the nutrient absorption (Fesseha, 2019). This may therefore increase the capacity of the intestine in absorbing the nutrients from feed (Purbarani et al., 2019). Overall, the increase in nutrient digestibility resulted in the improvement of nutrient utilization and hence improved the FCR of layer hens. Yet, the latter improvement did not accompanied by the increase in egg mass produced by the hens. This was consistent with previous study showing that probiotic Bacillus subtilis and Bacillus licheniformis (Mahdavi et al., 2005) and phytobiotics based on black cumin, thyme, cinnamon, ginger and pomegranate (Soliman and Kamel, 2020) did not significantly affect egg mass as well as feed consumption of laying hens.

\title{
CONCLUSION
}

The combined use of probiotics and phytobiotics improved physiological condition, ileal histomorphology, ileal protein digestibility and FCR of laying hens during post peak production. The combination of $1.2 \mathrm{~mL} /$ day of probiotic $L$. Acidophilus and $4 \%$ of phytobiotics resulted in the best outcomes for laying hens during post peak production.

\section{DECLARATIONS}

\author{
Corresponding Author \\ E-mail: sgh_undip@yahoo.co.id; ORCiD: 0000-0003-2445-0543
}

\section{Authors' Contribution}

All authors contributed in research and writing, equally.

\section{Conflict of interests}

The authors declare that they have no competing interests.

\section{REFERENCES}

Abudabos AM, Murshed MA, Qaid MM and Abdelrahman AG (2016). Effect of probiotics on serum biochemical and blood constituents in chicken challenged with Salmonella enterica Subsp typhimurium. Tropical Journal of Pharmaceutical Research. $15(3)$ : $461-467$. https://doi.org/10.4314/tjpr.v15i3.5 I Google Scholar

Babbar N, Dejonghe W, Gatti M, Sforza S and Kathy E, (2016). Pectic oligosaccharides from agricultural by-products: production, characterization and health benefits. Critical Reviews in Biotechnology, 36(4):594-606. https://doi.org/10.3109/07388551.2014.996732 I Google Scholar

Benítez V, Mollá E, Martín-Cabrejas MA, López-Andréu JF, Downes K, Terry LA and Esteban RM (2011). Characterization of industrial onion wastes (Allium cepa L.): dietary fibre and bioactive compounds. Plant Foods for Human Nutrition, 66(1): 48-57. https://doi.org/10.1007/s11130011-0212-x I Google Scholar

De Cesare A, Sirri F, Manfreda G, Moniaci P, Giardini A, Zampiga M, Meluzzi A (2017). Effect of dietary supplementation with Lactobacillus acidophilus D2/CSL (CECT 4529) on caecum microbioma and productive performance in broiler chickens. PloS ONE. $12(5)$ :e0176309. https://dx.doi.org/10.1371\%2Fjournal.pone.0176309 I Google Scholar

Chang $\mathrm{CH}$, Teng PY, Lee TT and Yu B (2019). Effects of multi-strain probiotics combined with Gardeniae fructus on intestinal microbiota, metabolites, and morphology in broilers. Journal of Poultry Science, 56: 32-43. https://doi.org/10.2141/jpsa.0170179 I Google Scholar 
Deko MK, Djuandi IH and Natsir MH (2018). Effect of using bulb flour and garlic skin (Allium sativum Linn) as a feed additive on the appearance of layer chicken production. Jurnal Ilmu-IImu Peternakan, 28: 192-202. https://jiip.ub.ac.id/index.php/jiip/article/view/466

Deraz SF (2018). Synergetic effects of multispecies probiotic supplementation on certain blood parameters and serum biochemical profile of broiler chickens. Journal of Animal Health and Production, 6(1): 27-34. https://doi.org/10.17582/journal.jahp/2018/6.1.27.34 I Google Scholar

Fesseha H (2019). Probiotics and its potential role in poultry production: A review. Veterinary Medicine Open Journal, 4: 69-76. http://dx.doi.org/10.17140/VMOJ-4-138 I Google Scholar

Haniarti H, Munir M, Akib MA, Ambar A, Rusman ADP and Abdullah A (2019). Herbal for increasing immunity and weight of poultry. IOP Conference Series: Earth and Environmental Science. 247. https://iopscience.iop.org/article/10.1088/1755-1315/247/1/012056/pdf Google Scholar I Google Scholar

Hedayati $M$ and Manafi $M$ (2018). Evaluation of an herbal compound, a commercial probiotic, and an antibiotic growth promoter on the performance, intestinal bacterial population, antibody titers, and morphology of the jejunum and ileum of broilers. Brazilian Journal of Poultry Science, 20(2): 305-316. https://doi.org/10.1590/1806-9061-2017-0639 I Google Scholar

Hussein E, Ahmed S.H, Abudabos AM, Aljumaah MR, Alkhlulaifi MM, Nassan MA, Suliman GM, Naiel M, \& Swelum AA (2020). Effect of antibiotic phytobiotic and probiotic supplementation on growth, blood indices and intestine health in broiler chicks challenged with clostridium perfringens. Animals, 10(3): 507. https://doi.org/10.3390/ani10030507 I Google Scholar

Ismoyowati D, Indrasanti, Mugiyono S and Pangestu M (2019). Phytogenic compounds do not interfere physiological parameters and growth performances on two Indonesian local breeds of ducks. Veterinary World, 12(11): 1689-1697. Google Scholar https://doi.org/10.14202/vetworld.2019.1689-1697

Jahanian R and Ashnagar M (2015). Effect of dietary supplementation of mannan-oligosaccharides on performance, blood metabolites, ilea nutrient digestibility, and gut microflora in Echerichia coli-challenged laying Hens. Poultry Science, 94(2): 2165-2172. https://doi.org/10.3382/ps/pev180 I Google Scholar

Kim YJ, Jin SK and Yang HS (2009). Effect of dietary garlic bulb and husk on the physicochemical properties of chicken meat. Poultry Science, 88(2): 398-405. https://doi.org/10.3382/ps.2008-00179 I Google Scholar

Krauze M, Abramowicz and Ognik K (2020). The Effect of addition of probiotic bacteria (Bacillus subtilis or Enterococcus faecium) or phytobiotic containing cinnamon oil to drinking water on the health and performance of broiler chickens. Annals of Animal Science, 20(1): 191-205. https://doi.org/10.2478/aoas-2019-0059 I Google Scholar

Lemme A, Ravindran V and Bryden WL (2004). Ileal digestibility of amino acids in feed ingredients for broilers. World's Poultry Science Journal. 60(4): 423-438. https://doi.org/10.1079/WPS200426 I Google Scholar

Mahdavi AH, Rahmani HR and Pourreza J (2005). Effect of probiotic supplements on egg quality and laying hen's performance. Internationa Journal of Poultry Science. 4(7): 488-492. https://dx.doi.org/10.3923/ijps.2005.488.492 I Google Scholar

Mateova S, Saly J, Tuckova M, Koscova J, Nemcova R, Gaalova M and Baranova D (2008). Effect of probiotics, prebiotics and herb oil on performance and metabolic parameters of broiler chickens. Medycyna Weterynaryjna. 64: 294-297. Link I Google Scholar

Purbarani SA, Wahyuni HI and Suthama N (2019). Dahlia inulin and Lactobacillus sp. in step down protein diet on villi development and growth of kub chickens. Tropical Animal Science Journal. 42(1): 19-24. https://doi.org/10.5398/tasj.2019.42.1.19 I Google Scholar

Rahman MM, Ripon MMR, Arefin MS, Ferdous MF, Rashid MH, Sani AA, Sultana MR, Hossain MT, Ahammad MU and Rafiq K (2019). Serum biochemical changes and growth response study following probiotic and phytobiotic supplementation in broiler chickens. AsianAustralasian Journal of Bioscience and Biotechnology, 4(1): 1-6. https://www.ebupress.com/journal/aajbb/wpcontent/uploads/sites/3/2019/08/1.pdf

Rahmawati D, Andika D and Fortunata SA (2019). Garlic peel extract phytochemical evaluation and extraction optimization. Journal of Functiona Food and Nutraceutical, 1: 41-46. https://doi.org/10.33555/jffn.v1i1.20

Risdianto D, Suthama N, Suprijatna E and Sunarso S (2016). Inclusion Effect of ginger and turmeric mixture combined with lactobacillus spp. isolated from rumen fluid of cattle on health status and growth of broiler. Journal of the Indonesian Tropical Animal Agriculture, 44(4): 423433. https://doi.org/10.14710/jitaa.44.4.423-433 I Google Scholar

Salim HM, Huque KS, Kamaruddin KM, and Beg M (2018). Global restriction of using antibiotic growth promoters and alternative strategies in poultry production. Science Progress, 101(1): 52-75. https://doi.org/10.3184/003685018X15173975498947 I Google Scholar

Santoso U, Fenita Y and Kususiyah K (2017). The Effect of medicinal herb inclusion on hematologic status and blood lipid profiles in broile chickens. International Journal of Poultry Science. 16. 415-423. http://dx.doi.org/10.3923/ijps.2017.415.423 I Google Scholar

Saputra YA, Mangisah I and Sukamto B (2016). The effect of adding onion peel flour to digestibility of crude protein feed, body weight gain and percentage of Mojosari duck carcass. Jurnal IImu-IImu Peternakan. 26(1): 29-36. https://jiip.ub.ac.id/index.php/jiip/article/view/232 I Google Scholar

Saputra YA, Suthama N and Sukamto B (2020). Feeding diets composed of low level microparticle protein derived from fish and soybean meals and using organic calcium added with lactobacillus acidophilus or citric acid on intestinal condition and performance of broilers. Livestock Research for Rural Development. 32(4). http://www.Irrd.org/Irrd32/4/yosep32068.html I Google Scholar

Siadati SA, Ebrahimnezhad Y, Jouzani GS and Shayegh J (2017). Evaluation of Probiotic Potential of Some Native Lactobacillus Strains on the Growth Performance and Serum Biochemical Parameters of Japanese Quails (Coturnix Coturnix Japonica) during Rearing Period. Brazilian Journal of Poultry Science. 19(3): 399-408. https://doi.org/10.1590/1806-9061-2016-0393 I Google Scholar

Sjofjan O, Adli DN, Hanani PK and Sulistyaningrum D (2019). The utilization of bay leaf (Syzygiumpolyanthum Walp) flour in feed on carcass quality, microflora instestine of broiler. International Journal of Engineering Technologies and Management Research, 6(11):1-9. https://doi.org/10.29121/ijetmr.v6.i11.2019.458 I Google Scholar

Soliman NK and Kamel SH (2020). Effect of herbs on productive performance of laying hens, some blood constituents and antioxidant activity in egg yolk. Egyptian Poultry Science Journal. 40(2): 493-505. https://doi.org/10.21608/epsj.2020.96095 I Google Scholar

Sufiriyanto N, Iriyanti I and Susanti E (2018). Haematology profiles and performance of broiler chickens fed on commercial feed. Anima Production. 20: 183-190. http://www.animalproduction.net/index.php/JAP/article/view/732/pdf

Sugiharto S, Yudiarti T, Isroli I, Widiastuti E, and Kusumanti E (2017). Dietary supplementation of probiotics in poultry exposed to heat stress - A Review. Annals of Animal Science. 17(3): 591-604. https://doi.org/10.1515/aoas-2016-0062 I Google Scholar

Tang S, Sieo CC, Ramasamy K, Saad WZ, Wong HK, and Ho YW (2017). Performance, biochemical and haematological responses, and relative organ weights of laying hens fed diets supplemented with prebiotic, probiotic and synbiotic. BMC Veterinary Research, 13(1):1-2. https://doi.org/10.1186/s12917-017-1160-y I Google Scholar

Yuanita I, Sunarti D, Wahyuni HI and Suthama N (2019). Feeding Dayak onion (Eleutherine palmifolia) extract and lactobacillus acidophilus mixture on blood biochemical, meat quality characteristics and growth performance in broiler chickens. Livestock Research for Rural Development. 31(9):144-9. http://www.Irrd.org/Irrd31/9/yuanit31144.html I Google Scholar

Zeka K, Ruparelia K, Arroo RRJ, Budriesi R and Micucci M (2017). Flavonoids and their Metabolites: Prevention in Cardiovascular Diseases and Diabetes. Diseases, 5(3): 19. https://dx.doi.org/10.3390\%2Fdiseases5030019 I Google Scholar 